DARIUSZ P. SKOWROŃSKI ${ }^{1}$, DANIEL JUSTIN FONG TAY2, MICHELLE HO WEN WAN², TOH SHI YING CHERIE2, TRICIA MARJORIE FERNANDEZ2, KATARZYNA WASZYŃSKA ${ }^{3}$

${ }^{1}$ Temple University Japan Campus, Tokyo

${ }^{2}$ Temasek Polytechnic, Singapore

${ }^{3}$ Adam Mickiewicz University, Poznań

\title{
INTRODUCTORY ANALYSIS OF FACTORS AFFECTING INTERCULTURAL COUPLES IN THE CONTEXT OF SINGAPORE
}

\begin{abstract}
Skowroński Dariusz P., Fong Tay Daniel Justin, Ho Wen Wan Michelle, Ying Cherie Toh Shi, Fernandez Tricia Marjorie, Waszyńska Katarzyna, Introductory Analysis of Factors Affecting Intercultural Couples in the Context of Singapore [Analiza czynników wpływających na funkcjonowanie związków międzykulturowych w Singapurze]. Studia Edukacyjne nr 30, 2014, Poznań 2014, pp. 263 286. Adam Mickiewicz University Press. ISBN 978-83-232-2756-4. ISSN 1233-6688

The intercultural marriages in Singapore have been on the rise in recent years and there is a growing need to present an analysis of potentially vital factors, which may play a significant role in couple dynamics from the cross-cultural perspective. The body of research found that mixed marriages and relationships tend to encounter more obstacles affecting the level of marital satisfaction than monocultural marriages. Therefore a deeper understanding of the factors affecting intercultural couples in Singapore seems to be a crucial introduction to the local context due to the paucity of prior research.
\end{abstract}

Key words: intercultural marriages, couple dynamics, marital factors, marital satisfaction

\section{Introduction}

In the context of Singapore, intercultural marriages have risen from 1761 marriages in the year of 2000 to 3550 marriages in the year of $2010 .^{1}$ The implication of the term "international marriage" involves a scope of relation-

1 Yearbook of statistics Singapore, 2011, Retrieved from: http:/ /www.singstat.gov.sg/pubn/ reference/yos11/yos2011.pdf. 
ships, which are an observed phenomenon of a marriage between two individuals of different nationalities. ${ }^{2}$ It has been observed that mixed marriages have been constantly increasing, but it was not until the last ten years that there has been a noticeable difference in numbers observed: 16.4 per cent of a total about 24,000 marriages in 2007 were intercultural unions compared to 8.9 per cent of about 25,000 marriages a decade before. ${ }^{3}$ This phenomenon of international marriage, as reflected in the Figures from Population in Brief 2010 showed that this trend continues to strengthen steadily, and the rough estimate of the number of non-citizen spouses married to Singapore citizens is 8,848 in 2009.4

With regards to interracial marriages, previous research conducted in the United States found an exceptional increase of interracial and intercultural marriages over the past thirty years. ${ }^{5}$ Nevertheless, for the upcoming 50 years, it is more than likely that marriages of such will continue to rise across cultures. ${ }^{6}$ However, such relationships are found to have a higher risk for failure, stressful conditions, divorce, and lower marital satisfaction rate, as compared to monocultural couples. Intercultural couples seem to have additional sources of difficulties, unlike monocultural couples which include macrocultural factors found in the family and society, and microcultural factors in the varying couple dynamics. ${ }^{7}$

\section{Motivations for intercultural marriage}

The United States Population Reference Bureau (2005) suggests that a contributing reason to the increase in numbers of intercultural marriages in recent years is due to the rate of immigration across the globe. Some of the reasons that could explain such a phenomenon are; military troops that have

${ }^{2}$ E. Tan, 'There shall be a status known as citizen of Singapore': international marriages in cosmopolitanising, patriarchal Singapore, Singapore $2006 .$.

${ }^{3}$ D.W. Tan, No mixed feelings over mixed marriages, The Straits Times 2010, January 31, Retrieved from: http://www.singaporeunited.sg/cep/index.php/web/News-Room/No-mixedfeelings-over-mixed-marriages.

4 National Population Secretariat, Singapore Department of Statistics, Ministry of Community Development, Ministry of Home Affairs and Authority 2010.

5 A.Y. Chan, K.R. Smith, Perceptions of marital stability in Black-White marriages, [in:] American Families: Issues in Race and Ethnicity, ed. C.K. Jacobson, New York 1995, p. 369-386; E. Ibrahim, D.G. Schroeder, Cross-cultural couples counselling: A developmental, psychoeducational intervention, Journal of Comparative Family Studies, 1990, 21, p. 193-205.

${ }^{6}$ M.W. Frame, The challenges of intercultural marriage: Strategies for pastoral care, Pastoral Psychology, 2004, 52 (3), p. 219-232. Retrieved from: http:/ / scholar.google.com.sg..

${ }^{7}$ D. Bhugra, P. De Silva, Couple therapy across cultures, Sexual and Relationship Therapy, 2000, 15, p. 183-192. 
been mobilized in different parts of the world, world trade, foreign exchange of students, tourism, mobility, and availability of money. ${ }^{8}$

Due to the globalization, the conventional social restrictions are being reduced, allowing young people to be more open for marital union with someone from a different country (Romano, 2001). Additionally, travelling for business or leisure is now easier than any other time hence more firms are sending their employees overseas. ${ }^{9}$

Programs that allow students to study abroad have also risen significantly over the past ten years. According to the data by the Institute of International Education (2006), the number of American students studying overseas, has more than doubled over the previous decade. Moreover, more than 560000 international students were enrolled in American universities and colleges. These statistics only show the trends in American society; therefore, it only gives a hint of the actual number of individuals crossing the borders to study worldwide, thus forming intercultural relationships.

The United States Population Reference Bureau (2005) also states that a contributing cause to the boost in numbers of intercultural marriages in recent years is also due to the increase of higher educational status in the population. Some studies found that higher education is positively correlated with more "liberal" thoughts towards assimilation across cultures, making one more open to the idea of dating people from other cultures. ${ }^{10}$

Char (1977) states that the reason why some Western men want to marry Japanese women is because of their perception that Japanese women tend to be more submissive. In a study done by Lee (2005), an American male confessed that he only wanted to marry an Asian wife due to this reason but then realized that his wife was the same as any American women.

The idea of "akogare", translated for a longing, desire or idealization, has been one of the motivations for Japanese women to marry White men. ${ }^{11} \mathrm{Kel}-$ sky (2001) discovered the three factors leading Japanese women to desire Western men: physical features, positive behavioural and attitudinal traits and peripheral qualities like ability to speak English well. All these traits tend to be rare in Japanese men.

${ }^{8}$ H.R. Sorley, Marital satisfaction in interethnic marriages between Mexican Americans and Anglo Americans - Unpublished master's thesis, Texas Tech University, Texas 1974.

9 B.R. Shepard, Deemed unsuitable, Toronto 1997.

${ }^{10}$ R. Farley et al., Stereotypes and Segregation: Neighborhoods in the Detroit Area, American Journal of Sociology, 1994, 100, p. 750-780; J.R. Kluegel, S.R. Eliot, Beliefs about inequality: Americans' views of what is and what ought to be, New York 1986; C.E. Case et al., Social Determinants of Racial Prejudice, Sociological Perspectives, 1989, 32, p. 469-48.

11 A. Kawamura, Examination of the self-expansion model in Japanese women-Caucasian men romantic relationships - Unpublished master's thesis, Hawaii 2005. 
Women from First World countries often resist the existing patriarchal family structure and norms. In Singapore, the local women tend to be selfreliant, making them less likely to marry down a man who seems weaker than her in terms of education and economic status. ${ }^{12}$ Singaporean women are often viewed by the local males as over open-minded, demanding and independent. ${ }^{13}$ Moreover, some Singaporean men hope to maintain their patriarchal privileges in today's society by wishing his wife to take on the traditional female gender role as a domestic homemaker and full-time housewife. Therefore, independent Singaporean women who are not prepared to take on these expectations, tend to employ better coping strategies to resist the predetermined norms by looking for foreign partners. ${ }^{14}$

People who are in a relationship with members of a different culture tend to be perceived as "morally degenerate", disobedient, and possess a low self-esteem. ${ }^{15}$ Contrasting with these stereotypes, most individuals in intercultural relationships not only respect their partners positively but also regard themselves positively. ${ }^{16}$ Porterfield (1978) reported that love was the main reason individuals married their partners, who were from a different cultural background.

$\mathrm{Fu}$ and Heaton (2000) stated that decisions to marry were affected by socioeconomic status, whereas Sung (1990) indicated, that those who marry outside of their cultures, are more likely to be eccentric, rebellious, and marrying for the second time, but also flexible when it comes to handling cultural differences. They are also willing to compromise and to accept traditions outside of their own culture.

\section{Marital Conflict}

Relationships are constructed differently and uniquely across each and every couple. However, conflicts are highly likely to occur, and act as potential barriers in each relationship. ${ }^{17}$ Just like any other regular couple, inter-

${ }^{12}$ R. Jongwilaiwan, Thai Woman and Marriage Migration in Singapore - Unpublished master's thesis, Singapore 2008.

${ }^{13}$ N. Constable, Cross-border marriages: gender and mobility in transnational Asia, Philadelphia 2005.

${ }^{14} \mathrm{R}$. Jongwilaiwan, Thai Woman.

${ }^{15}$ R.A.R. Gurung, T. Duong, Mixing and matching: Assessing the concomitants of mixed-ethnic relationships, Journal of Social and Personal Relationships, 1999, 16 (5), p. 639-657.

16 S.O. Gaines Jr., Relationships between members of cultural minorities, [in:] Understudied relationships: Off the beaten track, eds J.T. Wood, S. Duck, Thousand Oaks 1995, p. 51-88.

${ }_{17}$ C.J. Falicov, Cross-cultural marriages, [in:] Clinical handbook of couple therapy, eds N. Jacobson, A. Gurman, New York 1995, p. 231-246. 
cultural couples are no doubt faced with different sources of marital conflict in the process of their marriage. 18

Based on the context of intercultural couples, conflict is defined as "a mutually antagonized discrepancy between idealized expectations and the reality of insufficient resources, different personal goals and values, and impulses between the couples". ${ }^{19}$ Such discrepancies are often expressed through different cultural conflict styles, whereby intercultural conflict begins with miscommunication which subsequently leads to misinterpretations and pseudo-conflicts. ${ }^{20}$

A few sources of marital conflict for intercultural couples include varying couple dynamics consisting of cultural differences in language and communication, stereotypes, child rearing, and financial issues. Family factors are another source of marital conflict, and it consists of societal views, social support, family, and religion. Marital conflict is likely to affect the marital satisfaction of a couple which points to how successful a couple is in achieving what they hoped for in their marriage. ${ }^{21}$

\section{Couple Dynamics and Cultural Differences}

Couple dynamics refers to the characteristics that a relationship encompasses based on the level of traditionalism and mutual goals for such couples. ${ }^{22}$ The dynamics can refer to the level of commitment of being a couple or even the ways of expressing emotions to one's partner. ${ }^{23}$

Couple dynamics itself is very diverse and subjective for each couple, and this is even more so when it comes to intercultural couples. ${ }^{24}$ According to Takano (2002), 19\% of marital conflicts in intercultural couples is due to cultural differences. Cultural differences occur when intercultural couples fail to reach a compromise in terms of their cultural differences and similarities. When these couples enter a marriage, they make a transition which permits them to amend their cultural values and belief system, therefore,

\footnotetext{
${ }^{18}$ D. Romano, Intercultural marriages: Promises and pitfalls, Maine 2001.

19 J. Giles-Sims, Wife battering: A systems theory approach, New York 1983.

${ }^{20}$ S. Ting-Toomey, Managing intercultural conflicts effectively, Belmont 1994.

${ }^{21}$ H.R. Sorley, Marital satisfaction in interethnic marriages between Mexican Americans and Anglo Americans - Unpublished master's thesis, Texas 1974.

22 D.H. Sprenkle et al., Common factors in couple and Family therapy: The overlooked foundation for effective practice, New York 2009.

${ }^{23}$ S.N. Perkins, Influential Client Factors: Understanding and Organizing Therapists' Perceptions of Client Factors That Influence Reported Outcome of Therapy, Virginia 2010.

${ }^{24}$ G.J. Herr, Factors Influencing Black-White Interracial Marriage Satisfication, Texas 2009.
} 
making it possible for them to still uphold their own personal cultural values and beliefs. ${ }^{25}$ A study conducted by Jabar (2006) on Filipino women who were married to a foreigner of any nationality also discovered that cultural differences play a pivotal role in marital conflict.

Cultural differences usually include disparities in language and communication, cultural stereotypes, perspectives of financial handling, as well as child rearing and parenting style. To maintain a healthy intercultural relationship, it seems to be highly beneficial if couples share a strong sense of intimacy and mutual understanding of each other. ${ }^{26}$

A particular culture also influences a person's values, which are an individual's belief of systems and behaviour, determining whether a matter is considered right or wrong, and if it is an important issue or not. Being culturally derived, intercultural couples may often have differences in their values, which can cause conflict in their relationships. ${ }^{27}$

\section{Language and communication}

Kitivipart (1987) found that the communication is a key factor in maintaining marital satisfaction in intercultural relationships, whereby a lack of good communication with spouses often yields less contentment and happiness in the process.

Although many intercultural couples usually come from different backgrounds and have different mother tongue languages, it appears that the basis of communication is to have a mutual language as a mode of interaction. Taweekuakulkit (2005) noted that the communication barriers may occur if intercultural married couples do not have an agreement on a shared common language to use. Even when a mutual language is being used, potential barriers are very likely to come in their way as differences of communication behaviours may impact perception of criticism, changes in emotional state, and overall relationship satisfaction of mixed couples to a certain extent. ${ }^{28}$

${ }^{25}$ C.J. Falicov, Cross-cultural marriages, [in:] Clinical handbook of couple therapy, eds N. Jacobson, A. Gurman, New York 1995, p. 231-246.

${ }^{26}$ P.E. Heller, B. Wood, The influence of religious and ethnic differences on marital intimacy: Intermarriage versus intramarriage, Journal of Marital and Family Therapy, 2000, 26, p. 241-252.

27 D. Romano, Intercultural marriage: Promises and pitfalls (2nd ed.), Yarmouth, ME 1997.

${ }^{28}$ S.C. Galloway, Communication behaviour, perception of criticism, changes in emotional state, and relationship satisfaction in African, American and Caucasian heterosexual couples (Master's Thesis), Maryland 2006. 
According to Sechrest, Fay, and Zaidi (1972), there are five different language problems that pose as potential obstacles to be encountered by intercultural couples.

Firstly, an intercultural couple's vocabulary of their native language might differ due to their differences in background. An example would be that Americans may use many different words such as ebony, raven, inky, sable, coal black, and jet black to describe the shade of "black". However, on the other hand, one's Thai partner only uses one word to express "black" ${ }^{29}$ Hence, it is clear that problems in understanding can arise between members of different cultures as they may have different expectations as to what distinctions they should be able to express using their vocabularies. ${ }^{30}$

The next potential barrier would be idiomatic equivalence, whereby in every language there are idioms with the specific meaning that might not be familiar to people who do not use the language as a mother tongue. This is seen by Shade (1982) who observed that African Americans and Whites process and interpret messages differently, sharing different meanings of words or actions and having different rules for effective or appropriate behaviour. ${ }^{31}$ An example given in an American-Thai context, "the old man kicked the bucket" is understood by the Americans that the aged man died, whereas it could be interpreted by the Thais as that the aged man still is full of energy to have a sexual affair with a young woman. ${ }^{32}$

Thirdly, grammatical syntactical equivalency is a barrier in language communication between people with different native languages. Nouns, verbs, or adjectives differ in their position in a sentence, depending on the language addressed (e.g. "book a place" and "place a book"). Furthermore, a study whereby US and Canadian English speakers were surveyed, "Spray paint your car at our workshop" was being interpreted as asking the owner to spray paint on his or her own vehicle, whereas the Singapore English speakers interpreted it as going to the workshop to have his or her car

${ }^{29}$ N. Taweekuakulkit, Thai-North American intercultural marriage in the U.S.: A qualitative study of conflict from Thai wives' perspectives (Master's thesis), Wayne State University 2005, Volume 66-11, Section: A, p. 3866. 1969.

${ }^{30}$ B. Berlin, P. Kay, Basic Color Terms - Their Universality and Evolution, Berkeley-Los Angeles

${ }^{31}$ M.J. Collier, Cultural identity and intercultural communication, [in:] Intercultural communication: A reader, eds L.A. Samovar, R.E. Porter, Belmont, CA 1997, p. 337-347; M.J. Collier, M. Thomas, Cultural identity: An interpretative perspective, [in:] Theories in intercultural communication, eds Y.Y. Kim, W.B. Gudykunst, CA, Newbury Park 1988, p. 99-120.

32 N. Taweekuakulkit, Thai-North American. 
sprayed by the workers there. ${ }^{33}$ Once again, the differences in grammatical syntax are bound to cause misunderstanding during communication.

An intercultural couple's difference in their language experiences might also pose as a barrier. Cultural differences lead to differential experiences with the same language for an intercultural couple. Sometimes, an object or experience may not be represented in different cultures and languages, thus making it difficult to translate words that can correctly get the idea across. ${ }^{34}$ For example in the Singapore context, kiasu which means that one is afraid to lose in the Hokkien dialect; and karung guni which means rag-and-bone man in Malay, whereby both words are commonly used that might be hard to translate or explain to people of another culture. These words are widely accepted in Singapore, and even appear in national newspapers. ${ }^{35}$ Partners can thus expect difficulty in comprehension of certain expressions when a Singaporean speaks to a non-Singaporean who has a different English language experience due to their differences in background. Lastly, the conceptual underpinnings of several words in different cultures will lead to problems in communication. For example, there is a specific meaning of "freedom" to North Americans due to their history, which is viewed as the power to say, do, think and write as one desires to. On the other side, the Thais tend to take "freedom", as that the country is freed of colonization.

Lee (2005) found that English Monolinguals (EMs) tend to be irritated that their Korean-English Bilinguals (KEB) spouses do not understand a Westernized sense of humour; the Koreans seem to have different ideas, of what is meant to be funny and what is meant to be serious.

Furthermore, Lee (2005) also found that KEBs reported that they often lose arguments with their English native speaking spouse. They claimed that the one who had more power in their relationship was the one with the linguistic "upper hand". KEBs also feel frustrated with their linguistic inadequacy, but they did not suggest that their EM spouses should learn Korean, thus the obvious language choice in the household is English.

Additionally, Lee (2005) found that some of the KEB participants also feel frustrated whenever their ideas and content of their arguments are perfectly good, but they do not win the argument because they are unable to express these ideas in perfect English. However, EMs also suffers from language-related frustration. EMs find themselves losing patience with their

${ }^{33}$ L.D. Chang, Understand me or not? Accent, acceptability and intelligibility in international English: The case of Singapore (Master's Thesis), Singapore 2008. Retrieved from scholarbank.nus.edu.sg.

${ }^{34}$ N. Taweekuakulkit, Thai-North American.

${ }^{35}$ L.D. Chang, Understand me or not? 
spouses' imperfect English and also finding that they repeat the same linguistic mistakes again after repeatedly correcting them. On the other hand, KEBs are able to "vent" in Korean which gives them a sense of privacy. Their EM spouses are not emotionally affected by those hurtful comments as they do not understand Korean although they are aware that those negative and hurtful comments are about them. Hence, they can simply not listen to them.

Those who speak both Korean and English also tend to experience unfairness because they often get upset over their imperfect language skills, but their EM spouses will not. For instance, EMs will correct their spouses English during an argument. KEBs are also insecure about their inability to speak English fluently. This is especially so when EM spouses make this inadequacy more obvious, such as correcting their English in front of their friends. This will then lead the KEBs to 'lose face' which should be avoided for Koreans due to their cultural belief. ${ }^{36}$

In another study, Jabar (2006) found that Filipino women on average have lower education level as compared to their spouses; thus not being able to communicate in English very well. The wives were unable to translate their native language to English or to a language that their husbands could comprehend. These language differences aggravated marital disagreements when their husbands misunderstood what their wives were trying to say.

The language problem is not only a communication problem for intercultural couples, but also a problem on how they raise their children. In Lee's study (2005), some EMs complained that their KEB spouses rarely had conversations with their children but also complained about the use of imperfect English around them.

English is a widely used language all over the world and might be a mutual language for many intercultural couples. Singapore English - "Singlish" has been known to be distinctive, with much concern over the public's acceptance of this language. ${ }^{37}$ Although Singapore English has similar grammar standards with the proper English language, English accent tends to differ from country to country and possesses a unique accent in Singapore. Chang (2007) states that cultural backgrounds often impact one's accent in adaptation to a particular environment, as well as other frequently used

${ }^{36}$ J.H. Lee, Korean-English bilinguals (KEB) vs. English Monolinguals (EM): Language and international marriage partnership, Proceedings of the 4th International Symposium on Bilingualism, 2005.

${ }^{37}$ R.K. Tongue, The English of Singapore and Malaysia (2nd Ed.), Singapore 1979; P. Trudgill, J. Hannah, International English: A guide to the varieties of standard English (4th ed.), London 2002. 
languages (i.e. in Singapore context: Mandarin, Malay, and Chinese dialects). Singapore English has been labelled as "difficult to understand", and to pose as a genuine problem in communication. ${ }^{38}$ In an intercultural marriage a Singaporean, who is married to a foreigner of another culture, might encounter problems during communication due to their differences in accent when using the English language. Furthermore, anecdotal data found that the accent is one of the most widely mentioned barriers when communicating in spoken English. ${ }^{39}$

Barron (1951) and Biesanz (1950) discovered that in an intercultural marriage, learning how to speak the native language of the spouse tends to lead to a stable and happy marriage. Apart from the concerns of speaking the language itself, patterns of expressing oneself influence communications between couples. The patterns of communication are learnt since childhood and continue throughout adulthood. Disagreements between couples occur due to miscommunication as the partners tend to send and interpret messages based on their own cultural codes for communication. ${ }^{40}$

\section{Individualistic vs. Collectivistic Cultures}

Most cultures are either dominantly individualistic or collectivistic due to their backgrounds and also the environment. A collectivistic culture usually works as a group, and forms a "we" identity. ${ }^{41}$ On the other hand, an individualistic culture emphasises the "I" identity which values selfactualization, individual achievement, and personal qualities.

People in collective cultures tend to pay more attention to others' behaviour and status characteristics, communicating in an indirect way during interaction. ${ }^{42}$ Individuals in individualistic cultures are prone to act on their feelings, talk and communicate directly and interpersonally during interactions. ${ }^{43}$ Ting-Toomey (1994), related individualism-collectivism to the con-

${ }^{38}$ L.D. Chang, Intonation and intelligibility in Singapore English - Unpublished Honours Thesis, Singapore 1999.

${ }^{39}$ L.D. Chang, Understand me or not?

${ }^{40}$ C.L. Crippen, Working with intercultural couples and families: Exploring cultural dissonance to identify transformative opportunities, 2011, Retrieved from http://counselingoutfitters. com/vistas/vistas11/ Article_21.pdf

${ }^{41}$ G. Hofstede, Culture's consequences, Thousand Oaks 1980.

42 W.B. Gudykunst et al., Self-monitoring in Japan and the United States, [in:] Innovations in cross-cultural psychology, eds S. Iwawaki, Y. Kashima, K. Leung, Netherlands 1992, p. 185-198.

${ }^{43}$ A. Frymier, D. Klopf, S. Ishii, Japanese and American compared on the affect orientation construct, Psychological Reports, 1990, 66, p. 985-986. 
flict style, providing clear research evidence, that the role of the culture variability is critical in influencing the resolving of cross-cultural conflict. For instance, when a problem in the marriage arises, an individualistic partner might confront the problem directly in order to solve it. However, a collectivistic partner may engage in conflict avoidance, and promote peace within the relationship by using more indirect negotiation. ${ }^{44}$ For example, Koreans often feign their emotions around their White spouses in order to avoid conflict. 45 Therefore, couples from two different cultures may face certain problems while communicating thus careful negotiation is highly recommended.

\section{Cultural Stereotypes}

Just like a regular marriage, both spouses in an intercultural relationship have their specific roles to play, and they may vary across cultures. Cultural stereotypes often serve as a basis of what one's roles should be, leading to misunderstandings due to these distorted perceptions. When one creates expectations for others' behaviour and character based on the knowledge structure, a stereotype is formed. ${ }^{46}$ The sources of stereotypes may come from ideas portrayed by mass media that represent a particular culture or people as having the same type of behaviour and characteristics. Taweekuakulkit (2005) provided an example that the North Americans' views of Southeast Asian women as quiet, submissive, uncomplaining, and eager to serve, because of the reinforcement by their mass media, which often represent them as so.

However, these stereotypes may only be partially true, or even distorted, as many Asian women, especially younger Asian women tend to be an ill-fit for this stereotype. In fact, Coupland, Giles, and Wiemann (1991) found that many Asian women living in the States may appear to be quiet, not because of their culture, but because they are afraid to make mistakes when communicating in a second language.

Another example could be found in hardships, in American women married to Indian men when it comes to stereotypes in gender-specific roles. Indian men tend to think that they have to play the role of an American hus-

${ }^{44} \mathrm{R}$. Ma, The role of unofficial intermediaries in interpersonal conflicts in the Chinese culture, Communication Quarterly, 1992, 40, p. 269-278.

${ }^{45}$ J.H. Lee, Korean-English bilinguals (KEB) vs. English Monolinguals (EM).

${ }^{46}$ L.A. Jackson et al., The effects of stereotype consistency and consensus information on predictions of performance, Journal of Social Psychology, 1993, 133, p. 293-306. 
band, and American women are inclined to play the role of an Indian wife. This kind of perception led to mistrust in each other's cultures. ${ }^{47}$ Stereotypes might, in fact, be a source of pressure for an intercultural couple in terms of unrealistic expectations for each other. ${ }^{48}$

In Singapore context, majority of the Thai women, who marry local men, believe that they will receive financial support from their husbands after marriage. However, the stereotype of the Singaporean man as the "breadwinner" is often not true, and the Thai women have to reconstruct their gender roles as submissive to a diligent and financially independent wife. ${ }^{49}$

\section{Child Rearing}

With the arrival of an intercultural couple's first child, issues like religion and parenting style to raise a child often pose as a matter that requires careful consideration and needs to be negotiated; otherwise problems and disagreements may arise when a couple is unable to decide on which belief system should they pass on to their children. ${ }^{50}$ The critical concerns of child rearing include disciplinary methods which might differ for the two spouses due to their respective philosophy, values and beliefs.

In an intercultural family, couples are often faced with the everyday dilemmas of how to raise their child. For example, Jabar (2006) stated that it is common for Filipinos to punish their children, unlike their White spouses. Lee (2005) discovered that Koreans often punished their children if they do not succeed in their academics. However, their Westerner spouses are very relaxed towards their children, and this upsets their spouses. Koreans also expressed that their children would be confused if their parents had different punishment policies. Parenting preference is also an issue; White spouses of Filipino wives disagree with their belief of preferring their infant to sleep in the same room with them. ${ }^{51}$

With regards to parenting style, Perel (2000) states that most individuals adopt parenting styles their parents had for them. The parenting styles

${ }^{47}$ C. Merrill, Dishes on the drainboard, [in:] Swaying: Essays on intercultural love, eds J.C. Grearson, L.B. Smith, Iowa City, IA: 1995, p. 3-18.

${ }^{48}$ N. Coupland, H. Giles, J.M. Wiemann, Miscommunication and problematic talk, Newbury Park 1991.

${ }^{49}$ R. Jongwilaiwan, Thai Woman and Marriage Migration.

${ }^{50}$ C.L. Crippen, Working with intercultural couples and families.

${ }^{51}$ M.A. Jabar, Backgrounds of marriage: Conflict experiences of Filipino wives in intercultural marriages, Graduate Journal of Social Science, 2006, 3 (2), p. 43-57. 
adopted by two individuals from different cultures might be conflicting and contrasting within their family, depending on their own individual culture's view and practices.

Every culture has a pattern for raising children, and what is adaptive in one culture can be seen as maladaptive in another. For example, in general terms the Asian culture is more collectivistic one thus individuals are taught to work closely within the groups. Therefore, encouragement of independence would be seen as poor parenting in an Asian society. ${ }^{52}$

In addition to that, Malaysian parents represent a collectivistic culture, therefore; they tend to use an authoritarian parenting approach to their children to promote optimal development. Authoritarian parents are highly controlling, and they deal with disobedient children by forceful punishment. They are less inclined to praise, reward, and show affection. In this particular culture, authoritarian parenting does not reflect a seemingly negative style of parenting. Contrary to that, the authoritarian parenting style in the individualistic society is more likely to be labelled as a negative style as it is inconsistent with its culture's values. 53 Therefore, in an intercultural marriage, having two separate parenting styles can also cause marital disagreements as to which style should be promoted.

\section{Financial issues}

Another factor affecting couple dynamics in intercultural couples is the different perspectives in handling financial issues. Needless to say, money is often the main cause of concern to couples from an early stage of forming a partnership 54 through the separation of such bonds through divorce. ${ }^{55}$ Furthermore, disagreements over money may lead to marital tension and distress $^{56}$ and even separation. ${ }^{57}$

52 S. Keshavarz, R. Baharudin, Parenting style in a collectivist culture of Malaysia, European Journal of Social Sciences, 2009, 10 (1), p. 66-73.

53 Ibidem.

54 J.P. Marshall, L. Skogrand, Newlywed debt: The anti-dowry, The Forum for Family \& Consumer Issues 9, 2004, Retrieved August 3, 2007, from http://www.ces.ncsu.edu/ depts/fcs/pub/9_1/marshall.html.

${ }^{55} \mathrm{M}$. Benjamin, H. Irving, Money and mediation: Patterns of conflict in family mediation of financial matters, Mediation Quarterly, 2001, 18, p. 349-361.

$56 \mathrm{~J}$. Dew, Two sides of the same coin? The differing roles of assets and consumer debt in marriage, Journal of Family and Economic Issues, 2007, 28, p. 89-104.

${ }_{57}$ P.R. Amato, S.J. Rogers, A longitudinal study of marital problems and subsequent divorce, Journal of Marriage and the Family, 1997, 59, p. 612-624. 
For instance, Jabar (2006) found that marital problems arose when Filipino women were unable to control their spending. Additionally, these Filipino wives complained that their husbands were always taking charge of the finances, and not consulting them first before making the final decisions. ${ }^{58}$

In addition, Woelz-Stirling, Manderson, Kelaher, and Gordon (2000) found the disagreements between Filipino women married to Australian men due to financial issues. Filipinos usually possess economic independence and equal partnership in money matters. On the other hand, Australian men often make the decisions and sometimes refuse to let their wives work as they are often the main breadwinners in their culture. Olson and DeFrain (2000) showed that $37 \%$ of all interculturally married couples indicated that the main problem in their marriage was related to monetary issues.

Family members' perceived capacity to be involved in decision making about money, significantly affects their perceptions about social power, relative worth, and feelings of being valued in the family. ${ }^{59}$ All these problems can be seen to be further magnified especially so in intercultural marriages especially due to the difference in perceptions and culture differences.

\section{Societal views}

Societal attitudes exist on a spectrum from the curiosity to prejudice. 60 Society often perceives intercultural couples as non-conventional. Sometimes, couples do not want to be judged or be given judgmental looks by the public; therefore they do not appear to be together. Intercultural couples are often worried about public harassment. ${ }^{61}$

La Taillade (1999) states that the racial discrimination is a stressor to an intercultural relationship, as it impacts the number of negative spousal interactions and the general marital satisfaction. In a study of Black and White interracial couples by Killian (2001), $80 \%$ of the participants felt both personal pain and frustration from the seemingly negative reactions of the pub-

58 M.A. Jabar, Backgrounds of marriage: Conflict experiences of Filipino wives in intercultural marriages, Graduate Journal of Social Science, 2006, 3 (2), p. 43-57.

${ }^{59}$ L.M. Papp, E.M. Cummings, M.C. Goeke-Morey, For Richer, for Poorer: Money as a Topic of Marital Conflict in the Home, Family Relations, 2009, 58, p. 91-103.

${ }^{60}$ C. Sullivan, R.R. Cottone, Culturally based couple therapy and intercultural relationships: A review of the literature, The Family Journal: Counselling and Therapy for Couples and Families, 2006, 14 (3), p. 221-225.

${ }^{61}$ C.L. Crippen, Working with intercultural couples and families: Exploring cultural dissonance to identify transformative opportunities, 2011, Retrieved from http://counselingoutfitters.com/ vistas/vistas11/ Article_21.pdf 
lic to their relationship. This emotional hurt was the representation of both racism and intolerance in the society. Faulkner (1983), Karis (2003), and Wieling (2003) also suggest that individuals in society may intervene in an interracial relationship by divulging and making obvious their attitudes on interracial relationships when they interact with these couples.

Although the tolerance has risen, many Black-White couples experience discrimination acts from members of their own race; White Americans perceive mixed couples to be "too Black" and African Americans view them to be "not Black enough". ${ }^{62}$ Discrimination for Black-White couples is also found in the workplace. For example, problems associated with getting a job once the race of their spouse is made known exist. Also, individuals, who have been working a job for a long period, face discrimination as well, such as getting passed up for promotions, racially insensitive humour, and being left out of social events because of the race of the spouse. ${ }^{63}$ These reasons are likely to give rise to detrimental feelings or resentment within their relationship and ultimately causing poorer marital satisfaction between them.

Discrimination can also affect marital satisfaction by influencing the interaction patterns, and according to Foeman \& Nance (2002), Black partners often feel like their White partners are not aware of the level of discrimination they face in society, and thus they are the ones who have to point out the cases of discrimination and to take a lonesome stand. This can lead to a high amount of strain on the Black partner. ${ }^{64}$

In Singapore, local women who date or marry Caucasian men are often called 'Sarong Party Girls'. "Sarong" is traditional Malay formal clothing which is often worn by locals. As sarong was the expected dressing for parties held by Westerner expatriates in the past, 'Sarong Party Girls' eventually became a derogatory slur and stereotype referring to Singaporean women who only marry Whites for their money, and are hence looked down upon in Singapore's society. 65

62 M.P. Orbe, Communicating about "race" in interracial families, [in:] Communication, race, and family: Exploring communication in Black, White and biracial families, eds R.C. Diggs, T.J. Socha, New Jersey 1999.

${ }^{63}$ C. Luke, V. Carrington, Race matters, Journal of Intercultural Studies, 2000, 21, p. 5-25; S.A. Zebroski, Black-White intermarriages: The racial and gender dynamics of support and opposition, Journal of Black Studies, 1999, 30, p. 123-132.

${ }^{64}$ A. Foeman, T. Nance, Building new cultures, reframing old images: Success strategies of interracial couples, The Howard Journal of Communications, 2002, 13, p. 237-249; K.D. Killian, Dominant and marginalized discourses in interracial couples' narratives: Implications for family therapists, Family Process, 2002, 41, p. 603-618.

65 J. Aitchison, Sarong Party Girl, Angsana Books, 1994. 


\section{Social support}

Social support is a substantial factor in predicting marital satisfaction. Shute and Spitzberg (2003) found that as the amount of social support a couple receives increases, the levels of marital satisfaction experienced by intercultural couples also tend to increase. Social support is defined as the verbal and nonverbal communication between the individuals receiving the support and the individuals that are giving the support, such as family, friends, colleagues, and neighbours who have nothing against the marriage. ${ }^{66}$ Social support decreases anxiety and stress of intercultural marriage, and it also helps the couple to develop a sense of perceived control in these times of stress. ${ }^{67}$

Intercultural couples often have lesser mutual social network due to their differential backgrounds. Park \& Adelman (1983) found that a lack of mutual social networks is a prediction of probable marriage dissolution in intercultural couples. Therefore, friends and family should be needed as a common ground for interaction and support.

\section{Family members}

According to data in the United States, parents usually have negative connotations attached to the intercultural marriage, especially if it involves their own children. ${ }^{68}$ The couples' family often opposes the relationship and even after the couple got married; it is a common sight for most of the family members to skip the wedding ceremony. ${ }^{69}$

Initially, parents either ignore their children's intercultural relationship or accept it as a noncommittal one. In the latter scenario, when they come to the realization of their children's commitment, they usually stop their sup-

${ }^{66}$ G. Leatham, S. Duck, Conversations with friends and the dynamics of social support, [in:] Personal Relationships and Social Support, ed. S. Duck, London 1990, p. 1-29.

67 T.L. Albrecht, M.B. Adelman, Communicating social support: A theoretical perspective, [in:] Communicating Social Support, eds T.L. Albrecht, M.B. Adelman, Newbury Park 1987, p. 18-39.

${ }^{68}$ J.R. Davidson, L.J. Schneider, Acceptance of Black-White interracial marriage, The Journal of Intergroup Relations, 1992, 19 (3), p. 47-52; J.K. Mills et al., A note on family acceptance involving interracial friendships and romantic relationships, Journal of Psychology, 1995, 129, p. 349-351.

${ }^{69}$ E.C. Arnett, T. Pugh, Interracial unions rise despite society's same old prejudices, "San Diego Union Tribune", 1997, December 7, p. A29, A40; K.D. Killian, Dominant and marginalized discourses in interracial couples' narratives: Implications for family therapists, Family Process, 2002, 41, p. 603-618; S. Rosen, Intermarriage and the "blending of exiles" in Israel, Research in Race and Ethnic Relations, 1982, 3, p. 79-102. 
port. ${ }^{70}$ Traditional parents are most likely to show disappointments and disagreements with their children. Some parents fear of losing contact with their children, thus; they have no choice, but to accept the relationship. ${ }^{71}$ Usually, the parents would eventually approve the marriage, and cut-offs are highly unlikely. ${ }^{72}$ Therefore, a good relationship with both sides of the family will serve as a very important social capital and foundation for how a couple deals with issues at home. ${ }^{73}$

At first, most families usually do not display accepting attitudes towards intercultural marriage. However, after getting to know the spouse on a more personal level, acceptance will occur gradually, especially after the birth of a child. ${ }^{74}$ In the worst case scenario, some couples may even sever their family ties. ${ }^{75}$

Even after the acceptance stage, it is hard for each of the partners to understand each other's families. This is so especially when one of the spouses moves to their partner's country, thus not only facing difficulties adjusting to the move, but also adjusting to the behaviours of the partner's family. Wives would often face resentment by their husband's families due to his decision to outmarry. They also undergo challenges of being ill-treated by her in-laws. ${ }^{76}$ Furthermore, marital tension might occur if the partner in their home country is unaware of his or her spouse's isolation as an out-group in a foreign country. They also tend to experience cultural losses in terms of language, leisure, food, etc. ${ }^{77}$

The evidence of this kind of phenomena is reported in a study by Faulkner and Kich (1983) where they found, that White spouses in interracial relationships were significantly much more likely, in comparison to Black spouses, to experience a negative reaction regarding their relationship from

70 P. Stringer, Cross-community marriage in Northern Ireland: Social support and social constraints, Sexual and Marital Therapy, 1994, 9, p. 71-86.

${ }^{71}$ K.M. Kouri, M. Lasswell, Black-White marriages: Social change and intergenerational mobility, Marriage \& Family Review, 1993, 19, p. 241-255.

72 C. Joanides, M. Mayhew, P.M. Mamalakis, Investigating inter-Christian and intercultural couples associated with the Greek Orthodox Archdiocese of America: A qualitative research project, American Journal of Family Therapy, 2002, 30, p. 373-383.

73 C. Zhou, Chinese marriage migration in Singapore - Unpublished Honors Thesis, Singapore 2010 .

${ }^{74}$ K.M. Kouri, M. Lasswell, Black-White marriages.

75 B.L. Sung, Chinese American intermarriage, Journal of Comparative Family Studies, 1990, 21, p. 337-353.

76 A.E. Imamura, Strangers in a strange land: Coping with marginality in international marriage, Journal of Comparative Family Studies, 1990, 21, p. 171-191.

77 C.L. Crippen, Working with intercultural couples and families: Exploring cultural dissonance to identify transformative opportunities, 2011, Retrieved from http://counselingoutfitters.com/ vistas/vistas11/ Article_21.pdf. 
their families. It is, however, the Black partner in a Black-White interracial marriage that usually faces the greatest brunt of racial discrimination. ${ }^{78}$

When the extended family views the partner as an outsider, marital wellbeing will be negatively affected. Healthy boundaries between the couples' needs and the needs of the family must be established as it decreases the level of marital disagreements. Therefore, there must be a balance of needs between the individual, the couple, the nuclear and extended family. ${ }^{79}$

\section{Religion}

Intercultural couples come from different backgrounds and have a higher chance of holding different religious beliefs as compared to monocultural couples. Religion is an influential force within a family as it affects the different areas of their lifestyle, such as traditions, food, specific gender roles, sexuality, and even philosophy of raising a child. 80 The ignorance of the respective individual's faith communities have been found to result in marital discord especially after getting engaged, finding a place to marry, finding a mutually agreed worship site after marriage, and which religion their children should believe in. 81

In a study by Donovan (2004), it was found that having a partner of the same faith was an important factor in the building of their relationship and it also provided a sense of security for them. However should their religion both be very different from the other, intercultural couples will respond to such differences in various ways, such as practicing their own religion independently without forcing one's own religion on one's spouse, or converting to one's spouse's religion, adopting a third religion altogether, or keeping away formal religions. ${ }^{82}$ Such negotiation and compromising within an in-

78 C.L. Broman, Marital quality in black and white marriages, Journal of Family Issues, 2005, 26, 4, p. 431-441; A. Foeman, T. Nance, Building new cultures, reframing old images: Success strategies of interracial couples, The Howard Journal of Communications, 2002, 13, p. 237-249; K.D. Killian, Crossing borders: Race, gender, and their intersections in interracial couples, Journal of Feminist Family Therapy, 2001, 13, 1; E.M. Walker, Interracial couples: The impact of race and gender on one's experience of discrimination based on the race of the partner, College Park 2005.

${ }^{79}$ C. Joanides, M. Mayhew, P.M. Mamalakis, Investigating inter-Christian and intercultural couples associated with the Greek Orthodox Archdiocese of America: A qualitative research project, American Journal of Family Therapy, 2002, 30, p. 373-383.

${ }^{80}$ M.W. Frame, The challenges of intercultural marriage.

${ }^{81}$ C. Joanides, M. Mayhew, P.M. Mamalakis, Investigating inter-Christian and intercultural couples associated.

82 D. Romano, Intercultural marriage: Promises and pitfalls (2nd ed.), Yarmouth, ME 1997. 
tercultural couple is not likely to affect their marital satisfaction adversely in the long run.

\section{Conclusion}

The presented theoretical analysis, based on the observable data, that the intercultural marriages globally and in Singapore have been on the rise in the recent years, opens up a new research field within the psychological studies in Singapore's context with regards to the analysis of significant factors affecting marital satisfaction amongst intercultural couples. The presented analysis contribute to the discussion about the future social trends and offers insights into the dynamically changing local communities, resulting in growing diversity of Singaporean society, which is one of the most dynamically changing places in the world. This is because Singapore is a cosmopolitan city, attracting an influx of foreigners from all over the world, and, therefore affecting the social fabric of Singapore, thanks to the strong foundation of inter-ethnical ties and the atmosphere of acceptance in Singapore.

\section{BIBLIOGRAPHY}

Aitchison J., Sarong Party Girl, Angsana Books, 1994.

Albrecht T.L., Adelman M.B., Communicating social support: A theoretical perspective, [in:] Communicating Social Support, eds T.L. Albrecht, M.B. Adelman, Newbury Park, CA: Sage, 1987.

Amato P.R., Rogers S.J., A longitudinal study of marital problems and subsequent divorce, Journal of Marriage and the Family, 1997, 59.

Arnett E.C., Pugh T., Interracial unions rise despite society's same old prejudices, "San Diego Union Tribune", 1997, December 7.

Barron M.L., Research on intermarriage: a survey of accomplishments and prospects, American Journal of Sociology, 1951, 57.

Benjamin M., Irving H., Money and mediation: Patterns of conflict in family mediation of financial matters, Mediation Quarterly, 2001, 18.

Berlin B., Kay P., Basic Color Terms - Their Universality and Evolution, University of California Press, Berkeley-Los Angeles 1969.

Biesanz J., Inter-American marriages on the Isthmus of Panama, Social Forces, 1950, 29.

Bhugra D., De Silva P., Couple therapy across cultures, Sexual and Relationship Therapy, 2000, 15.

Broman C.L., Marital quality in black and white marriages, Journal of Family Issues, 2005, 26, 4.

Case C.E., Greeley A.M., Fuchs S., Social Determinants of Racial Prejudice, Sociological Perspectives, 1989, 32. 
Chan A.Y., Smith K.R., Perceptions of marital stability in Black-White marriages, [in:] American Families: Issues in Race and Ethnicity, ed. C.K. Jacobson, Garland, New York 1995.

Char W.F., Motivations for Intercultural Marriages, [in:] Adjustment in Intercultural Marriage, eds W. Tsung, J.F. McDrmott, T.W. Maretzki, The University Press of Hawaii, Honolulu, HI 1977.

Chang L.D., Intonation and intelligibility in Singapore English - Unpublished Honours Thesis, Department of English Language and Literature, National University of Singapore, Singapore 1999.

Chang L.D., Understand me or not? Accent, acceptability and intelligibility in international English: The case of Singapore (Master's Thesis), National University of Singapore, Singapore 2008. Retrieved from scholarbank.nus.edu.sg.

Collier M.J., A comparison of intracultural and intercultural communication among and between domestic culture groups: How intra- and intercultural competencies vary, Communication Quarterly, 1988, 36.

Collier M.J., Cultural identity and intercultural communication, [in:] Intercultural communication: A reader, eds L.A. Samovar, R.E. Porter, Wadsworth, Belmont, CA 1997.

Collier M.J., Thomas M., Cultural identity: An interpretative perspective, [in:] Theories in intercultural communication, eds Y.Y. Kim, W.B. Gudykunst, CA: Sage, Newbury Park 1988.

Constable N., Cross-border marriages: gender and mobility in transnational Asia, University of Pennsylvania Press, Philadelphia 2005.

Coupland N., Giles H., Wiemann J.M., Miscommunication and problematic talk, CA: Sage, Newbury Park 1991.

Crippen C.L., Working with intercultural couples and families: Exploring cultural dissonance to identify transformative opportunities, 2011, Retrieved from http://counselingo utfitters.com/vistas/vistas11/ Article_21.pdf

Davidson J.R., Schneider L.J., Acceptance of Black-White interracial marriage, The Journal of Intergroup Relations, 1992, 19 (3).

Dew J., Two sides of the same coin? The differing roles of assets and consumer debt in marriage, Journal of Family and Economic Issues, 2007, 28.

Donovan S., Stress and coping techniques in successful intercultural marriages - Unpublished master's thesis, Faculty of the Virginia Polytechnic Institute and State University, Virginia 2004.

Falicov C.J., Cross-cultural marriages, [in:] Clinical handbook of couple therapy, eds N. Jacobson, A. Gurman, Guilford, New York 1995.

Farley R., Steeh C., Krysan M., Jackson T., Stereotypes and Segregation: Neighborhoods in the Detroit Area, American Journal of Sociology, 1994, 100.

Faulkner J., Women in interracial relationships, Women \& Therapy, 1983, 2.

Faulkner J., Kich G.K., Assessment and engagement stages in therapy with the interracial family, [in:] Cultural perspectives in family therapy, ed. C.J. Falicov, Aspen Systems, Rockville Md. 1983.

Foeman A., Nance T., Building new cultures, reframing old images: Success strategies of interracial couples, The Howard Journal of Communications, 2002, 13.

Frame M.W., The challenges of intercultural marriage: Strategies for pastoral care, Pastoral Psychology, 2004, 52 (3), p. 219-232. Retrieved from: http:/ / scholar.google.com.sg. 
Frymier A., Klopf D., Ishii S., Japanese and American compared on the affect orientation construct, Psychological Reports, 1990, 66.

Fu X., Heaton T.B., Status exchange in intermarriage among Hawaiians, Japanese, Filipinos and Caucasians in Hawaii: 1983-1994, Journal of Comparative Family Studies, 2000, 31.

Gaines S.O. Jr., Relationships between members of cultural minorities, [in:] Understudied relationships: Off the beaten track, eds J.T. Wood, S. Duck, CA: Sage, Thousand Oaks 1995.

Galloway S.C., Communication behaviour, perception of criticism, changes in emotional state, and relationship satisfaction in African, American and Caucasian heterosexual couples (Master's Thesis), University Maryland, Maryland 2006.

Giles-Sims J., Wife battering: A systems theory approach, Guilford, New York 1983.

Gudykunst W.B., Gao G., Nishida T., Nadamitsu Y., Sakai J., Self-monitoring in Japan and the United States, [in:] Innovations in cross-cultural psychology, eds S. Iwawaki, Y. Kashima, K. Leung, Swets \& Zeitlinger, Lisse, Netherlands 1992.

Gurung R.A.R., Duong T., Mixing and matching: Assessing the concomitants of mixed-ethnic relationships, Journal of Social and Personal Relationships, 1999, 16 (5).

Heller P.E., Wood B., The influence of religious and ethnic differences on marital intimacy: Intermarriage versus intramarriage, Journal of Marital and Family Therapy, 2000, 26.

Herr G.J., Factors Influencing Black-White Interracial Marriage Satisfication, University of Texas, Texas 2009.

Hofstede G., Culture's consequences. CA: Sage, Thousand Oaks 1980.

Ibrahim E., Schroeder D.G., Cross-cultural couples counselling: A developmental, psychoeducational intervention, Journal of Comparative Family Studies, 1990, 21.

Institute of International Education, 2006 Annual report, 2006, Retrieved from: http:// www.iie.org/en/Who-We-Are/Annual-Report/ /media/Files/Corporate/AR/2006 -IIE-Annual-Report.ashx.

Imamura A.E., Strangers in a strange land: Coping with marginality in international marriage, Journal of Comparative Family Studies, 1990, 21.

Jabar M.A., Backgrounds of marriage: Conflict experiences of Filipino wives in intercultural marriages, Graduate Journal of Social Science, 2006, 3 (2).

Jackson L.A., Hansen C.H., Hansen R.D., Sullivan L.A., The effects of stereotype consistency and consensus information on predictions of performance, Journal of Social Psychology, 1993, 133.

Joanides C., Mayhew M., Mamalakis P.M., Investigating inter-Christian and intercultural couples associated with the Greek Orthodox Archdiocese of America: A qualitative research project, American Journal of Family Therapy, 2002, 30.

Jongwilaiwan R., Thai Woman and Marriage Migration in Singapore - Unpublished master's thesis, National University of Singapore, Singapore 2008.

Karis T.A., How race matters and does not matter for White women in relationships with Black men, [in:] Clinical issues with interracial couples, eds V. Thomas, T.A. Karis, J.L. Wetchler, New York 2003.

Kawamura A., Examination of the self-expansion model in Japanese women-Caucasian men romantic relationships - Unpublished master's thesis, University of Hawaii, Hawaii 2005.

Kelsky K., Women on the verge: Japanese women, Western dreams, Duke University Press, London 2001.

Keshavarz S., Baharudin R., Parenting style in a collectivist culture of Malaysia, European Journal of Social Sciences, 2009, 10 (1). 
Killian K.D., Crossing borders: Race, gender, and their intersections in interracial couples, Journal of Feminist Family Therapy, 2001, 13, 1.

Killian K.D., Dominant and marginalized discourses in interracial couples' narratives: Implications for family therapists, Family Process, 2002, 41.

Kitivipart L., Communication and interaction styles in Thai-American cross-cultural marriage, Ph.D. Dissertation in Psychology, International University, School of Human Behaviour, San Diego 1987.

Kluegel J.R., Eliot S.R., Beliefs about inequality: Americans' views of what is and what ought to be, Aldine de Gruyter, New York 1986.

Kouri K.M., Lasswell M., Black-White marriages: Social change and intergenerational mobility, Marriage \& Family Review, 1993, 19.

La Taillade J.J., Predictors of satisfaction and resiliency in African American/White interracial relationships - Unpublished doctoral dissertation, University of Washington, Seattle1999.

Leatham G., Duck S., Conversations with friends and the dynamics of social support, [in:] Personal Relationships and Social Support, ed. S. Duck, Sage, London 1990.

Lee J.H., Korean-English bilinguals (KEB) vs. English Monolinguals (EM): Language and international marriage partnership, Proceedings of the 4th International Symposium on Bilingualism, 2005.

Luke C., Carrington V., Race matters, Journal of Intercultural Studies, 2000, 21.

Ma R., The role of unofficial intermediaries in interpersonal conflicts in the Chinese culture, Communication Quarterly, 1992, 40.

Marshall J.P., Skogrand L., Newlywed debt: The anti-dowry, The Forum for Family \& Consumer Issues 9, 2004, Retrieved August 3, 2007, from http://www. ces.ncsu.edu/depts/fcs/pub/9_1/marshall.html.

Mills J.K., Daly J., Longmore A., Kilbride G., A note on family acceptance involving interracial friendships and romantic relationships, Journal of Psychology, 1995, 129.

Merrill C., Dishes on the drainboard, [in:] Swaying: Essays on intercultural love, eds J.C. Grearson, L.B. Smith, University of Iowa Press, Iowa City, IA 1995.

National Population Secretariat, Prime Minister's Office, Singapore Department of Statistics, Youth \& Sports Ministry of Community Development, Ministry of Home Affairs and Immigration \& Checkpoints Authority, "Population in brief 2010", Singapore 2010.

Olson D.H., DeFrain J., Marriage and the family: Diversity and strengths, Mayfield, Mountain View, CA 2000.

Orbe M.P., Communicating about "race" in interracial families, [in:] Communication, race, and family: Exploring communication in Black, White and biracial families, eds R.C. Diggs, T.J. Socha, Erlbaum, New Jersey 1999.

Papp L.M., Cummings E.M., Goeke-Morey M.C., For Richer, for Poorer: Money as a Topic of Marital Conflict in the Home, Family Relations, 2009, 58.

Park M.R., Adelman M.B., Communication networks and the development of romantic relationships: an expansion of uncertainty reduction theory, Human Communication Research, 1983, 10.

Perkins S.N., Influential Client Factors: Understanding and Organizing Therapists' Perceptions of Client Factors That Influence Reported Outcome of Therapy, Virginia Polytechnic Institute and State University, Virginia 2010.

Porterfield E., Black and White mixed marriages, Nelson-Hall, Chicago 1978. 
Perel E., A tourist's view of marriage, [in:] Couples on the fault line, ed. P. Papp, Guilford, New York 2000.

Romano D., Intercultural marriage: Promises and pitfalls (2nd ed.), Intercultural Press, Yarmouth, ME 1997.

Romano D., Intercultural marriages: Promises and pitfalls (2nd ed), Intercultural Press, Inc., Maine 2001.

Rosen S., Intermarriage and the "blending of exiles" in Israel, Research in Race and Ethnic Relations, 1982, 3.

Sechrest L., Fay T.L., Zaidi S.M., Problem of translation in cross-cultural communication, [in:] Intercultural Communication: A Reader (5th edition), eds L.A. Samovar, R.E. Porter, Wadsworth, Belmont, CA 1988.

Shade B.J., Afro-American cognitive style: A variable in school success, Review of Educational Research, 1982, 52.

Shepard B.R., Deemed unsuitable, Umbrella Press, Toronto, ON 1997.

Shute C., Spitzberg B., Intercultural couples: examining the role of social support, A paper presented to the Hawaii International Conference on Social Sciences, June 12-15, 2003.

Sorley H.R., Marital satisfaction in interethnic marriages between Mexican Americans and Anglo Americans - Unpublished master's thesis, Texas Tech University, Texas 1974.

Sprenkle D.H., Davis S.D., Lebow J.L., Common factors in couple and Family therapy: The overlooked foundation for effective practice, Guilford, New York 2009.

Sullivan C., Cottone R.R., Culturally based couple therapy and intercultural relationships: A review of the literature, The Family Journal: Counselling and Therapy for Couples and Families, 2006, 14 (3).

Stringer P., Cross-community marriage in Northern Ireland: Social support and social constraints, Sexual and Marital Therapy, 1994, 9.

Sung B.L., Chinese American intermarriage, Journal of Comparative Family Studies, 1990, 21.

Takano Y., Experience of domestic violence and abuse of Japanese immigrant women: an existential and phenomenological study (Master's thesis), Trinity Western University, Canada 2002.

Tan D.W., No mixed feelings over mixed marriages, The Straits Times 2010, January 31, Retrieved from: http://www.singaporeunited.sg/cep/index.php/web/News-Room/ No-mixed-feelings-over-mixed-marriages

Tan E., 'There shall be a status known as citizen of Singapore': international marriages in cosmopolitanising, patriarchal Singapore, Conference on International Marriage, Rights and the State in Southeast and East Asia, Asia Research Institute, National University of Singapore, Singapore 2006.

Taweekuakulkit N., Thai-North American intercultural marriage in the U.S.: A qualitative study of conflict from Thai wives' perspectives (Master's thesis), Dissertation Abstracts International, Wayne State University 2005, Volume 66-11, Section: A.

Ting-Toomey S., Managing intercultural conflicts effectively, Intercultural Communication (7th ed.), Wadsworth, Belmont, CA 1994.

Tongue R.K., The English of Singapore and Malaysia (2nd Ed.), Eastern Universities Press, Singapore 1979.

Trudgill P., Hannah J., International English: A guide to the varieties of standard English (4th ed.), Arnold, London 2002.

United States Population Reference Bureau, New Marriages, New Families: U.S. Racial and Hispanic Intermarriage. Population Bulletin 2005, June, 60, p. 1-36, from http://www.prb.org/pdf05/60.2NewMarriages.pdf. 
Walker E.M., Interracial couples: The impact of race and gender on one's experience of discrimination based on the race of the partner, University of Maryland, College Park 2005.

Wieling E., Latino and White marriages: A pilot study investigating the experiences of interethnic couples in the United States, [in:] Clinical issues with interracial couples: Theories and research, eds V. Thomas, T.A. Karis, J.L. Wetchler, Haworth, New York 2003.

Woelz-Stirling N., Manderson L., Kelaher M., Gordon S., Marital conflict and finances among Filipinas in Australia, International Journal of Intercultural Relations, 2000, 24.

Yearbook of statistics Singapore, 2011, Retrieved from: http://www.singstat.gov.sg/ pubn/reference/yos11/yos2011.pdf.

Zebroski S.A., Black-White intermarriages: The racial and gender dynamics of support and opposition, Journal of Black Studies, 1999, 30.

Zhou C., Chinese marriage migration in Singapore - Unpublished Honors Thesis, Department of Sociology, National University of Singapore, Singapore 2010. 